\title{
How Memoranda of Understanding Have Affected EU Democratic Institutions in Southern EU Countries
}

\author{
Anastasia Chr. Lekka (Corresponding author) \\ Fellow Professor at the University of Thessaly \\ Department of Economics, Greece
}

Received: November 24, 2016 Accepted: December 23, 2016 Published: August 10, 2017

doi:10.5296/ijssr.v5i2.11692ＵＵＵ： Uttp://dx.doi.org/10.5296/ijssr.v5i2.11692

\begin{abstract}
The recent recession having emerged in 2007 has been the worst economic downturn since the time of Great Depression of 1929 in USA and spread across the European continent. In many European countries this led to severe sovereign debt crisis beginning in 2010 and was followed by implementation of austerity measures with significant impact on public, social and employment sector. Those tough austerity measures resulted in structural reforms of welfare and labor market especially in Southern EU countries like Greece, Spain, Portugal, Ireland and Italy representing the most prominent examples. These policies were imposed to a large extend through the so called "Troika" which was an interaction between internal EU and external Organizations, like the European Union, the European Central Bank and International Monetary Fund respectively.

Citizens realize that their national economic institutions are no longer responsible for the decision making on major social and economic policies, on economic and welfare policies, on privatization and sale of public assets. Consequently, citizens tend to question if this constrained democracy deserves further support. This is enhanced by the fact that National Parliaments no longer develop policies but rather align with policies dictated by the above stated Institutions and are forced to accept such deals without asking the opinion of citizens. Nevertheless the EU intends to promote civil society participation in decision making and program policies applied. This contradiction needs to be analyzed in order to determine if there is a democratic deficit in EU member states.
\end{abstract}

Keywords: sovereign debt crisis, austerity, civil society participation, democratic deficit

\section{Introduction}

Dramatic budget shrinking and harsh austerity measures aiming at fiscal adjustment bring 
about changes in the social fabric of ailing countries. Such austerity measures include wage cuts, debilitating of public services and weakening of social protection. Such measures are dictated by the EU economic model which is market-driven, advocating deregulation, liberalization instead of man-oriented social investment.

Faced with an unprecedented economic crisis which was mostly felt in Southern European countries, the EU economic paradigm inflicted upon these countries a heavy blow to the social net and the welfare state. A cascade of severe cuts in allowances and benefits, slashing of salaries and pensions, direct and indirect taxes, foreclosures due to bad loans, bankruptcies, personnel dismissals have resulted in rising pauperization almost causing low income groups vanish into thin air and middle income groups become the "new poor" generation.

The financial crisis was soon transformed into a social crisis.

\section{Democracy in Dire Straits}

In this context, the population in the afflicted countries is increasingly contesting the social foundation of the European integration project. The EU membership has always been synonymous to solidarity, social justice, better perspectives for growth and mobility in the EU. Nevertheless, the protracted economic crisis combined with harsh austerity measures has eroded the social and man-oriented character of Europe. The EU fixes objectives and puts in place instruments to combat poverty and reduce the number of destitute people in Europe (e.g EU 2020 Strategy); in addition, the EU has fixed as its goal to eliminate the risk of social exclusion threatening particularly the most vulnerable social groups.

Nevertheless, youth unemployment and redundancy in elderly age groups, having been intensified due to the economic crisis and the persistent austerity measures, run contrary to the European idea of a 'Social Europe', hence a paradox is rising. Austerity measures undermine any solid socially-oriented foundation. Populations and geographical regions are polarized; geographical discrepancies turn into economic and social divergence: The rich of the North and the poor of the South.

There is, however, still time to steer Europe away from a sterile and socially suffocating economic model towards more balanced policy options that would combine economic growth, social investment and prosperity; the Nordic countries are a case in point that is worth to examine. They enjoy fiscal balance and economic stability, supporting at the same time citizens through a welfare model.

The Nordic model is well-known as it manages to combine free trade market with social democracy and welfare benefits. Despite the different options in each Nordic country, they all place special emphasis on a welfare model that is fully committed to social cohesion. The Nordic countries rank in the highest position with regard to workers' rights protection on the International Trade Union Confederation's 2014 Global Rights Index; Denmark is the country with the highest score. However, this nice balance described could be easily overturned as is the case with Finland. The Government announced 40 bn cuts of which 20 bn to be cut by 2020; social partners opposed strongly to such an announcement and took to the streets manifesting against such curtails. Therefore, although Finland has been very 
judgmental towards the countries of the South in a very disparaging way, it now seems that the economic hardships are migrating to the rich North.

In search of the causes behind the Memorandum of Understanding in EU Member States in Southern Europe, the following arguments need to be underscored driving us to certain concrete findings:

- Transatlantic Trade Investment Partnership (TTIP). TTIP heralds the New Status. This notorious agreement has been concocted with the aim to unite the USA and the EU into a single economic area, creating thus the biggest global market for the free movement of goods, commodities and services. It seems that the United States of America intended to place under their wings the countries just opposite their East and West Coast, trying to anticipate or even outflank the rivals, Russia-China, before they become stronger and more 'attractive' economic partners. It becomes very obvious that the scope of this endeavor spans across both sides of the Atlantic; what is less obvious though is that such a partnership is premised upon the equalization of policies between USA-EU as both sides of the Atlantic will become inextricably linked with Washington -obviously- taking the lead, or even being the 'boss'. Germany would have a hard time accepting coming second. Maybe this explains the big blow to German car industry in the aftermath of the VW scandal.

TTIP shall take effect in a very important sector, namely the public sector. In particular, it will be possible for private enterprises to get a foothold in the public services. Such private undertakings will be able to offer healthcare services, education, water supply e.t.c. with no restriction whatsoever but simply on grounds of being more cost-effective.

Notwithstanding the public services sector, TTIP takes its toll of the private sector as well. Big multinational companies wish to overshadow and eventually outstrip small local businesses that will not be able to sustain the pressure and will collapse for the benefit of big multinationals.

In a nutshell, TTIP epitomizes the contraction and retrenchment of all regulatory provisions that include labor rights, environmental rules, food safety rules (USA intends to spread GMOs around the world, unrestricted use of hormones and pesticides), personal data protection etc. It is the breach of personal freedoms and rights because they stand in the way of multinationals' profitability. TTIP foresees a full abolishment of collective bargaining agreements and trade union rights. Besides, it is worth to mention that the USA has not ratified to date the contracts of the International Labor Organization.

As regards citizens' food safety, it all appears that the European Union has already succumbed to TTIP by withdrawing Phytosanitary protection laws by virtue of this partnership.

In light of the above, TTIP is a tool for dismantling democracy. One of its mechanisms is the introduction of the so-called Investor-State Dispute Settlement 
(ISDS) between states and investors. In detail, this practically means that multinational companies shall be entitled to bring a government before justice should the latter adopt policies that would entail profit loss for the enterprises. How democratic does it sound? Non-elected multinational companies will be able to determine and dictate policies to democratically elected governments. This mechanism, ISDS is already valid in other trade agreements across the globe; for example, the Swedish energy company Vattenfall has sued the German government on grounds of deciding to phase out stepwise the nuclear power plants in the aftermath of the Fukushima disaster.

Based on the above, TTIP is not simply an agreement; looking ahead into the future, we see the world being dominated by economic vested interests being represented by big multinational companies clashing with any democratic aspect (Williams, 2015).

- Democratic deficit in the EU mechanisms. The economic crisis was transformed into a democratic crisis generating a democratic deficit both within countries and at European level. This deficit is illustrated in the weakness of national governments to hold the helm of governance. Although national governments are legitimately the decision-makers, they are not capable though of choosing amongst various alternatives to overcome the crisis. Austerity measures and rigorous fiscal adjustment programmes are dictated by international market-driven bodies and funds. For example, the European Central Bank is a powerful institution able to impose conditions regarding on money creation and the way it will be used. In practice, the ECB is more powerful than the democratically elected domestic governments and can influence their decisions. The unaccountable ECB exerts power over the markets and may impose policies (Donatella della Porta, July 2015).

One manifestation of democratic misfunction is the non-involvement of civil society in decision making processes. For democracy to be substantive, it should transcend a simple set of rules, laws, regulations and practices. The overriding principle should involve translating civic values into mechanisms and actions expressing them. The European Economic and Social Committee is an advisory EU institution created precisely to enable the civil society take part in decision making process. It consists of associations, employers, employees, trade unions, farmers, small and medium sized enterprises, merchants, cooperatives, consumers associations, NGOs etc. In this way, civil society's role is upgraded and reinforced by promoting dialogue on key policy issues.

However, this is not the case in practice as the EESC has not been successful in delivering on its statutory role. A political group at the European Parliament, the Alliance of Liberals and Democrats for Europe (ALDE) published a position paper suggesting considering the possibility of abolishing the EESC. This proposal speaks volumes of the mistrust vis-à-vis the EESC.

- All austerity measures and fiscal adjustment programmes are premised, inter alia, on the need of debt-ridden states to generate revenue. Privatisation is usually advocated 
as the key solution to generate revenue. The Troika demands that crisis-hit countries privatize their state assets and public services. However, the solution of privatization is inherently undemocratic as it involves taking away nations' sovereignty and conceding it to large corporate undertakings, namely multinational companies. History has shown that such waves of privatisations have not been particularly successful in generating the anticipated profits. For example, in Britain, the rail industry, the water system in Madrid and the historic buildings and assets in Italy. A case in point is France's water services which used to be privately-owned and were transferred to municipalities. This transfer was successful in cost-saving (Zacune, 2013).

- Political leadership and democracy. The economic crisis, as shown with depression and rampant inflation, does create the conditions for undemocratic political demagogues and political parties. Political leaders with academic background from American Universities have adopted a New Status mentality, globalization-oriented and seem to be less interested in Europe and the European family interests. This leads to the adoption of Memorandum of Understanding with all the austerity measures imposed on national economies.

- Weakness of linking the monetary union with the political union. This weakness results in the adoption of both ineffective and not legitimate measures. Political unity is not simply a rhetorical ploy to justify devolution of power to supranational formations like the E.U. It is a practical need dictated by the current developments. The Eurocrisis has unveiled a hidden vicious circle and a paradox at the heart of Europe: the monetary union inflicting upon ailing countries harsh austerity measures that cause a deep social crisis and affect democracy. Yet, the consolidation and stabilization of democracy has been a key EU achievement and a prerequisite for a Member State's EU membership. Many EU Member States experienced non-democratic regimes in the past 100 years, or even 50 years under authoritarian rule. A country's EU adhesion pre-supposed its democratic transformation. In order to join the EU, a country should meet rigorous criteria pertaining to freedom, democracy, respect for human rights and fundamental freedoms and the rule of law. A political union that would respect democracy involves respecting the democratic identity of each Member State and recognizing local particularities. An economic paradigm based on 'one size fits all' approach would end up suffocating small, debt-ridden countries of the South (Greece, Portugal), causing unprecedented social crisis, far from the ideal of an ever closer union of peoples' (Bellamy, 2013).

Moreover, pursuant to the Lisbon Treaty 2009, it is important to highlight that the European Commission plays the role of EU 'quasi-government' and enjoys the approval of the European Parliament. Nevertheless, despite this parliamentary control, criticism is mounting as regards the fact that the European Commission is not an elected body; hence it does not have a democratic legitimacy.

In consideration of the above, it is easily understood that economy and democracy are two 
concepts inextricably linked that should complement each other instead of clashing with each other. Probing into the aforementioned causes and casting light on the economic and social crisis profile, we are faced with the following paradox: the shrinking of democratic institutions in the EU combined with the effort to develop economic and political institutions to the Western standards in the Central and Southeastern Europe region. We would like to recall that the EU has elaborated contractual relations with Western Balkans countries, the so-called stabilization and association agreements (Lekka, 2012). Notwithstanding the economic and commercial aspects of such agreements, provision is also made for democratization, assistance, promotion of civil society, education and institutional development, promotion of political dialogue. The European Union has largely invested in helping Southeastern European countries in their transformation process by underpinning their economic and political reforms. A case in point is the pre-accession process in the case of Turkey, the European Neighborhood Policy with countries from Eastern Europe and the Mediterranean, e.g. the Eastern Partnership and Union for the Mediterranean initiatives. The recent funding instrument ENI (European Neighborhood Instrument) replaced the European Neighborhood and Partnership Instrument (ENPI) (2007-2013) and constitutes one of the biggest instruments made available by the EU for its neighboring countries. The amounts to be allocated within the context of this Instrument stand at $€ 15$ bn for the period 2014-2020. A large sum out of this funding is earmarked for Democracy and Human Rights and stands at approximately €1,333 million (www.enpi-info.eu/ENI, 5/11/2015).

The EU support to democratization processes and to market economy has been a well-established practice since the fall of Socialism and onwards. This was achieved via many programmes and especially funding in order to support good governance in the neighboring countries, the rule of law, public administration overhaul, freedom in education and protection of human rights, fundamental rights and minorities.

One could wonder though, what is the drive behind the EU leading it/or forcing it to follow un-democratic practices? Is it all ascribed to the new international political and socioeconomic landscape? The new international arena seeks to consolidate globalized governance with very small margins of national freedoms and maneuvering and an economic regime dependent on large multinational companies. Such regimes do not provide for high participation and representation levels of civil society.

\section{Conclusion}

In conclusion, it all boils down to a political or even philosophical conundrum. What kind of Europe we are aiming at? What is the vision of Europe we all envisage? Is it a trans-national association of states operating under the mechanisms of a private profit-oriented enterprise, engulfed in ruthless competition and market-driven mechanisms? Or maybe we are aiming at a social and democratic Europe of nations with responsible and accountable citizens? Member States, old ones and recent members included, certainly need to keep abreast with modern developments in technology, economy, commerce, innovation; member states shall be called upon to revamp their administration, restructure their obsolete state mechanisms and structures, overhaul their healthcare systems and labor markets; nevertheless, what they 
should leave unaltered is the set of universal values and principles underlying the entire European foundation. Mechanisms may be outdated and in need of reform; values and democracy should endure in time.

\section{Acknowledgements}

This article was presented at the conference entitled 'Democracy and Economy', which was organized by the Department of Economics, University of Thessaly in November 2015.

\section{References}

Anastasia Lekka, The New Architecture of Regional Cooperation in Southeastern Europe and Black Sea, Herodotos, Athens, 2012

Christos J. Paraskevopoulos, 'Accounting for variation in the impact of and response to economic crisis in Southern Europe: institutional performance and policy learning capacity in Greece and Portugal, University of Macedonia, 2011

Donatella Della Porta, ‘A 12 step guide to the EU’s crisis of political responsibility’, 2015

Joseph Zacune, 'Privatising Europe Using the Crisis to Entrench Neoliberalism', Working Paper, published by the Transnational Institute, Amsterdam, March 2013. (www.enpi-info.eu/ENI, 5/11/2015)

Lee Williams, 'What is TTIP? And six reasons why the answer should scare you', $\begin{array}{llll}\text { Independent, } \quad \text { Monday, } & \text { October } & 12,\end{array}$ http://www.independent.co.uk/voices/comment/what-is-ttip-and-six-reasons-why-the-answershould-scare-you-9779688.html

Maria Petmesidou \& Ana Guillén, 'Economic crisis and austerity in Southern Europe: threat or opportunity for a sustainable welfare state?’, OSE Paper Series, January 2015

Pavlos Eleftheriadis, 'Democratic Accountability for a Monetary Union', UCL European Institute, The Eurozone Crisis and the Democratic Deficit, 2013

Richard Bellamy, 'The Democratic Deficit, Social Justice and the Eurozone Crisis', UCL European Institute, The Eurozone Crisis and the Democratic Deficit, 2013.

Ulrike Guérot, 'Solidarity, Democracy and the Eurocrisis', UCL European Institute, The Eurozone Crisis and the Democratic Deficit, 2013

\section{Copyright Disclaimer}

Copyright for this article is retained by the author(s), with first publication rights granted to the journal.

This is an open-access article distributed under the terms and conditions of the Creative Commons Attribution license (http://creativecommons.org/licenses/by/3.0/). 